(c) Elsevier/INRA

Original article

\title{
Gynodioecy and mitochondrial DNA polymorphism in natural populations of Beta vulgaris ssp maritima
}

\author{
J Cuguen ${ }^{1,2}$, R Wattier ${ }^{2}$, P Saumitou-Laprade ${ }^{2}$, D Forcioli ${ }^{2}$, \\ M Mörchen ${ }^{2}, \mathrm{H}$ Van Dijk ${ }^{2}$, P Vernet ${ }^{2}$ \\ 1 Université de Lille 1, Institut Agricole et Alimentaire de Lille, \\ 59655 Villeneuve-d'Ascq Cedex ; \\ 2 Université de Lille 1, Laboratoire de Génétique et Évolution des Populations, \\ URA CNRS 1185, Bâtiment SN2, 59655 Villeneuve-d'Ascq Cedex, France
}

\begin{abstract}
Summary - Gynodioecious populations of Beta vulgaris ssp maritima were found all along the French coasts; $42 \%$ of the populations were gynodioecious. Locally, there were large sex-ratio differences between populations, ranging from 0 to $76 \%$ of females. This large variation was even found between populations less than $1 \mathrm{~km}$ apart. Molecular analysis of mitochondrial polymorphism revealed a high variability; 11 different mitochondrial types were found. The Nvulg type, which is the most frequent type among the maintainers of male sterility used in sugar beet breeding programs, was also the most frequent type in natural populations. Conversely, the characteristic pattern of the Owen CMS (cytoplasmic male sterility), ie the Svulg type, was not found. The mitochondrial variability detected within the populations was large; there were 2.10 different mitotypes on average among the 5 individuals sampled per population. There was a highly significant overall difference in mitotype frequencies between populations $(F s t=0.466 ; P<0.001)$, distributed both between $(F s t=0.138 ; P<0.001)$ and within regions $(F s t=0.381 ; P<0.001)$. Female plants were found with almost all of the different mitotypes. Nevertheless, 2 groups of mitotypes were clearly distinguished: the mitotypes Nvulg, A and B were rarely associated with the female phenotype, whereas female plants were often found among the plants having the mitotypes $\mathrm{E}$ and $\mathrm{G}$.
\end{abstract}

sex-ratio variation / gynodioecy / cytoplasmic male sterility / mtDNA polymorphism / Beta vulgaris ssp maritima

Résumé - Gynodioécie et polymorphisme mitochondrial chez Beta vulgaris ssp maritima. Des populations gynodioïques sont rencontrées dans toutes les régions prospectées ( $42 \%$ des populations étudiées). Localement, la fréquence des plantes femelles varie fortement entre les populations, depuis une complète absence jusqu'à 76\% de femelles. Cette forte variation se rencontre entre populations proches, distantes de moins d'1 $\mathrm{km}$. $L$ 'analyse du polymorphisme de l'ADN mitochondrial a révélé l'existence de 11 types mi- 
tochondriaux. Le mitotype Nvulg, caractéristique des mainteneurs de stérilité mâle utilisés dans les programmes d'amélioration de la betterave sucrière, est le type le plus répandu dans les populations naturelles. En revanche, le type Svulg, rencontré chez les plantes de cytoplasme CMS (cytoplasmic male sterility) Owen, en est complètement absent. La variabilité intrapopulation est forte : en moyenne 2,1 mitotypes parmi les 5 individus échantillonnés par population. La différenciation interpopulations de la fréquence des mitotypes est hautement significative (Fst $=0,466 ; P<0,001)$, répartie aussi bien entre régions $(F s t=0,138 ; P<0,001)$ qu'entre les populations dans les régions ( $F s t=0,381 ; P<0,001)$. Des plantes femelles sont trouvées avec tous les types mitochondriaux. Néanmoins, 2 groupes peuvent être distingués : d'une part les mitotypes Nvulg, $A$ et $B$ qui, quelle que soit la région considérée, sont rarement portés par des plantes femelles, d'autre part les mitotypes $E$ et $G$ qui sont toujours associés à de fortes fréquences de femelles.

variation du sex-ratio / gynodioécie / stérilité mâle cytoplasmique / polymorphisme de l'ADNmt / Beta vulgaris ssp maritima

\section{INTRODUCTION}

Gynodioecy, defined as the occurrence of both male sterile (female) and hermaphroditic plants within natural populations, is observed in a wide array of plant taxonomic groups: $7.5 \%$ of the angiosperm species display this breeding system (Delannay, 1978; Kaul, 1988). Male sterility is also a genetic resource widely used for plant breeding due to its convenience for performing controlled crosses and for the commercial production of hybrid cultivars. Consequently, the evaluation of the diversity of this resource, as well as the identification of its genetic and molecular determinants are of great interest.

The distribution of gynodioecious populations and the sexual phenotype frequencies vary widely among species. In different species of thyme, all populations studied are gynodioecious, although there is a remarkably large variation in female frequency among populations: between 10 and $95 \%$ in Thymus vulgaris (Dommée et al, 1983; Belhassen et al, 1989); between 17 and $87 \%$ in Thymus zygis; and between 41 and $99 \%$ in Thymus mastichina (Manicacci, 1993). Conversely, in some other species like plantains, the frequencies of male steriles are lower, between 4 and $22 \%$ in Plantago lanceolata (Van Damme, 1984), and 5 and $27 \%$ in Plantago coronopus (Koelewijn, 1993). Finally, in other species including Armeria maritima, gynodioecious populations are only found in a restricted part of the distribution area of the species (Baker, 1966; Vekemans et al, 1990). Male sterility has been frequently reported in wild beet (Mikami et al, 1985; Halldén et al, 1988, 1990; Mann et al, 1989). Previous studies have focused on the estimation of female frequency variation, as well as on the origin of the maintenance of male steriles at high frequency in natural populations (Boutin et al, 1987, 1989; Saumitou-Laprade et al, 1993). Highly contrasting frequencies of male steriles $(19 \%$ and $62 \%$ ) have been observed in 2 natural populations from a small estuary on the French coast of the English Channel (Boutin et al, 1987, 1989). 
In almost all of the gynodioecious species studied, male sterility is controlled by nuclear and cytoplasmic interaction (Kheyr-Pour, 1980, 1981; Van Damme, 1983; Kaul, 1988; Belhassen et al, 1991; Koelewijn 1993). The sexual phenotype of the plant is the result of the interaction between a sterilising cytoplasmic component and a variable number of nuclear suppressors of male sterility (called restorer genes of male fertility). In cultivated beet, cytoplasmic male sterility (CMS) has long been used for the production of hybrid lines (Owen, 1945). In wild beet, the genetic determination of male sterility is also nucleo-cytoplasmic, but the cytoplasmic factors involved differ from those used in the breeding programs of cultivated sugar beet (Boutin et al, 1987).

The existence and the maintenance of females in gynodioecious species have puzzled evolution biologists for a long time (at least since Darwin, 1877), and have attracted considerable attention, both theoretical and empirical. From a theoretical point of view, the existence of females at high frequency in populations is unexpected. As females can be considered as hermaphroditic individuals having lost their male function, they suffer from a 2-fold disadvantage in the transmission of their genes to the next generation. Thus, in order to persist in populations, they must have a compensatory advantage in some components of fitness (see Couvet et al, 1990, for a review).

Molecular analyses of several plant species have connected the expression of male sterility with chimeric genes in the mitochondrial genome (Hanson, 1991). Plant mitochondria have an active recombination system. Chimeric genes are believed to be one of the consequences of molecular rearrangements; different open reading frames are joined together and cotranscribed, in addition to standard mitochondrial genes.

In plants, including wild gynodioecious species, the degree of mitochondrial molecular polymorphism is poorly known. Data from the literature suggest a wide range of variation among species. In Thymus vulgaris, more than 30 different hybridisation patterns have been found among 200 individuals from 15 populations (Atlan, 1991). At the other extreme, only 3 mitochondrial types have been identified in Plantago lanceolata, each correlated to one of the 3 different cytoplasms implicated in male sterility in this species (Rouwendal et al, 1987). In Beta vulgaris ssp maritima, 5 different mitochondrial types have been found within 2 populations (Boutin et al, 1987; Saumitou-Laprade et al, 1993).

In this study we have tried to answer the following questions:

(i) What is the proportion of gynodioecious populations in Beta vulgaris ssp maritima, and what is the variation of the frequency of male steriles in natural populations?

(ii) What is the degree of mitochondrial molecular polymorphism and how is it distributed among populations?

(iii) What is the relationship between this polymorphism and the occurrence of male sterility in this species? 


\section{MATERIALS AND METHODS}

\section{The species}

Beta vulgaris ssp maritima, wild beet, is a wind-pollinated, short-lived perennial and gynodioecious species. Some of its populations contain hermaphroditic and male sterile individuals (females), characterised by their inability to produce efficient pollen. The species is widely distributed along the coasts of Western Europe and around the Mediterranean Basin. Beta vulgaris ssp maritima belongs to the same species as cultivated beet (leaf, table, fodder and sugar beets referred to as Beta vulgaris ssp vulgaris), and represents the wild relative of these taxa.

\section{Plant material}

Two sampling schemes were used to determine the distribution of gynodioecy. First, 93 natural populations were sampled in 1989 during a collecting mission in collaboration with INRA (Prof $\mathrm{H}$ Laby) and USDA (Dr DL Doney). The populations sampled were located on the French Mediterranean, Atlantic, English Channel and North Sea coasts, and the coasts of Belgium, the south Netherlands and south-eastern England. Some inland populations located in south-western France (Gers and Lot-et-Garonne) were also sampled. Individual open pollinated progenies were collected in each population and sown in the experimental garden of the University of Lille. The sexual phenotype of a average of 8.9 individuals per population ( $\mathrm{SD}=7.0$ ) was determined. A population was considered as gynodioecious if at least one male sterile plant was observed among the offspring. This method yields a conservative estimate of the proportion of gynodioecious populations as some populations can be incorrectly scored as non-gynodioecious due to the small sample size.

Secondly, during June 1990, additional samples were collected to estimate the local female frequency variation. The coasts between Le Hourdel (Baie de Somme) in France and Burghsluis (Zeeland) in the Netherlands were investigated. Populations of wild beet in this region are predominantly found in the estuaries of coastal rivers. Thirty-three populations from 10 estuaries were sampled. In each population, the sexual phenotype of almost all the flowering individuals was scored.

\section{Molecular analysis}

Thirty-eight of the total of 93 populations were randomly selected for molecular analysis of mitochondrial polymorphism; 5 individuals per population were analysed. Their sexual phenotype was determined to establish the relationship between mitochondrial polymorphism and male sterility.

Restriction fragment length polymorphism (RFLP) of mitochondrial DNA was analysed as follows. Total DNA was isolated from fresh leaves, digested with EcoRI, subjected to electrophoresis and transferred to nylon membranes using a vacuum Southern transfer apparatus. Several mitochondrial probes labelled with digoxigenin were hybridised. Hybridisation profiles were visualised by immunological detection and chemiluminescence (Saumitou-Laprade et al, 1993). In a previous study 
(Saumitou-Laprade et al, 1993), 9 mitochondrial probes were used to test for polymorphism, and 2 were shown to be highly discriminative. These 2 probes were used in this study: a heterologous probe from maize, ATPase subunit 6 (Dewey et al, 1985); and a non-coding mitochondrial sequence from sugar beet, pBv4 (SaumitouLaprade et al, 1993). Neither of these 2 probes distinguished between Beta maritima N2 and Beta vulgaris Nvulg mitochondria, although their EcoRI restriction profiles are clearly different (Saumitou-Laprade et al, 1993). Thus, the $12.5 \mathrm{~kb}$ EcoRI fragment of mtDNA in the Nvulg restriction pattern and absent from the N2 pattern was used as a differential probe. This fragment called 'Nvulg/N2' was isolated from an EcoRI digest of mtDNA by $0.8 \%$ agarose gel electrophoresis and was purified using the Qiaex procedure (Diagen). No cloning step was used, and $1 \mu \mathrm{g}$ of this DNA was labelled with digoxigenin and used as a probe in the hybridisations.

\section{Genetic data analysis}

Differences in mitotype frequencies among populations within regions and between regions were analysed using $F$-statistics for haploid data (Excoffier et al, 1992).

\section{RESULTS}

\section{Gynodioecy in wild beet populations}

Gynodioecious populations were found in all the regions sampled (fig 1). In $42 \%$ of the populations, at least 1 male sterile was observed among the plants characterised for their sexual phenotype. The proportion of gynodioecious populations varied between the different regions: from $23 \%$ along the coast of the Channel to $71 \%$ among the populations from the Mediterranean coast (table I). Within the north region, the variation of male sterile frequencies was large (table II). Male steriles were not found in all of the estuaries. Female frequency varied widely between populations (from 0 to $76 \%$ ); in some cases the local variation was large between populations less than $1 \mathrm{~km}$ apart.

Table I. Frequencies of gynodioecious and non-gynodioecious populations within the different regions sampled.

\begin{tabular}{|c|c|c|}
\hline Region & No of populations & Proportion of gynodioecious populations \\
\hline North & 13 & 0.23 \\
\hline Brittany & 36 & 0.42 \\
\hline Biscay & 33 & 0.45 \\
\hline Gers & 4 & 0.25 \\
\hline Mediterranean & 7 & 0.71 \\
\hline Total & 93 & 0.42 \\
\hline
\end{tabular}




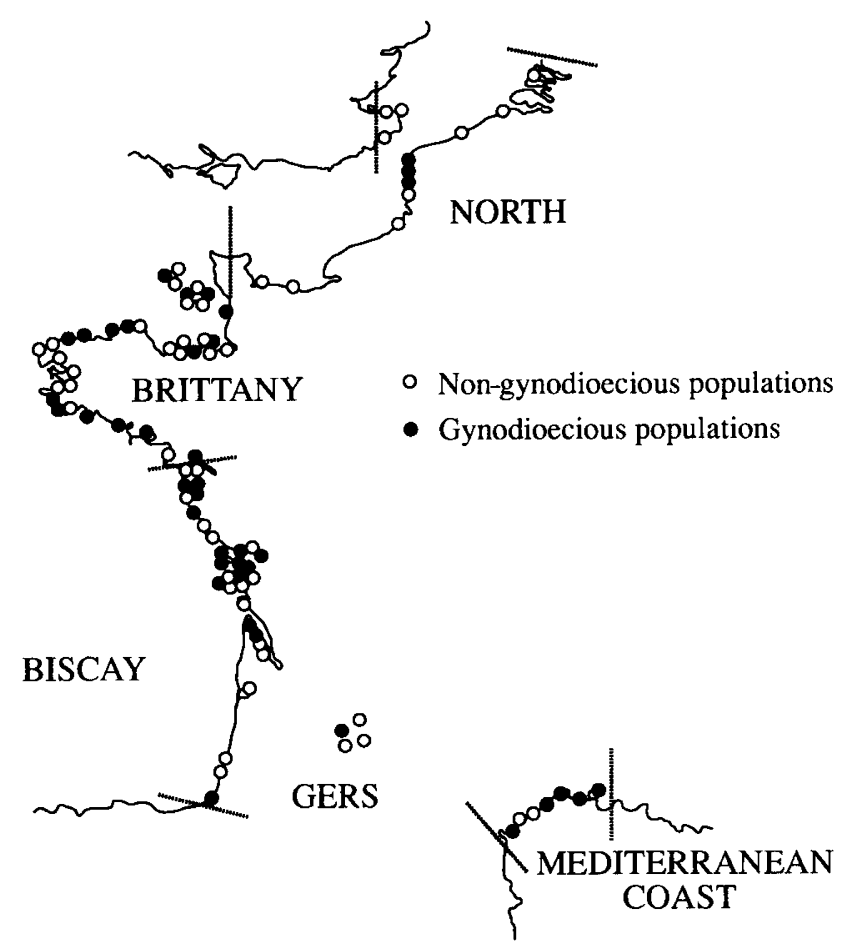

Fig 1. Distribution of gynodioecious and non-gynodioecious populations in the studied area.

Table II. Frequencies of female plants in populations located along the continental coast of the Channel.

\begin{tabular}{lcccc}
\hline Sites & $\begin{array}{c}\text { No of populations } \\
\text { per site }\end{array}$ & $\begin{array}{c}\text { No of flowering } \\
\text { plants sexed }\end{array}$ & $\begin{array}{c}\text { Mean proportion } \\
\text { of female plants }\end{array}$ & $\begin{array}{c}\text { Within-site range } \\
\text { of the proportion } \\
\text { of female plants }\end{array}$ \\
\hline Burghsluis & 1 & 46 & 0 & - \\
Zwin & 1 & 53 & 0 & - \\
Zeebrugge & 1 & 15 & 0 & - \\
Nieuwpoort & 1 & 94 & 0 & 0 \\
Slack & 5 & 396 & 0.096 & $0-0.750$ \\
Wimereux & 7 & 1266 & 0.147 & $0-0.765$ \\
Canche & 11 & 1143 & 0.479 & $0.083-0.660$ \\
Authie & 3 & 596 & 0.037 & $0-0.240$ \\
Pointe d'Offoy & 1 & 193 & 0 & - \\
Le Hourdel & 2 & 320 & 0 & 0 \\
Total & 33 & 4122 & 0.192 & - \\
\hline
\end{tabular}




\section{Polymorphism of the mitochondrial DNA}

Five different variants were revealed by the $\mathrm{pBv} 4$ probe; 4 of these have been reported previously (Saumitou-Laprade et al, 1993) and a new pattern characterised by a single $4.4 \mathrm{~kb}$ band was found in this study. Seven different variants were identified by the Nvulg/N2 probe. The variants 1, 2, 3, 4, and 6 are presented in figure 2. Only 2 hybridisation profiles, both previously identified (SaumitouLaprade et al, 1993), were detected with the atp6 probe. The combination of the different variants obtained with each probe was used to define mitochondrial types or mitotypes, designated A to J. Eleven different mitotypes were observed in this study (table III and fig 3): 5 were previously identified by Saumitou-Laprade et al, 1993 , and the $\mathrm{H}$ type had been found among inland adventice beet by Boudry et al (1993).
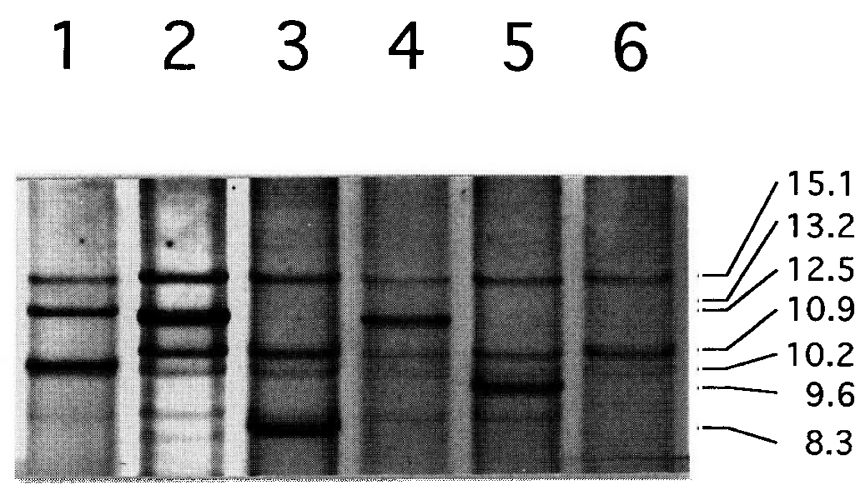

Fig 2. Southern blot analysis of EcoRI-digested total DNA with the Nvulg/N2 probe. Lanes 1, 3, 5, 6: Beta vulgaris ssp maritima; lanes 2, 4: Beta vulgaris ssp vulgaris. Lane 1: mtDNA type $\mathrm{H}$; lane 2, 4: mtDNA type Nvulg (O type); lane 3: mtDNA type B (N3); lane 5: mtDNA type C (N2); lane 6: mtDNA type E (S). Molecular weights were estimated by comparison with lambda DNA digested by EcoRI and HindIII.

Table III. mtDNA polymorphism revealed by hybridisation of 3 mitochondrial probes to EcoRI digested total DNA. The different patterns revealed by each probe are designated by numbers. The designations in brackets refer to Saumitou-Laprade et al 1993.

\begin{tabular}{|c|c|c|c|c|c|c|c|c|c|c|c|c|}
\hline \multirow[t]{2}{*}{ Probes } & \multirow[t]{2}{*}{ Nvulg } & \multicolumn{10}{|c|}{ Mitochondrial DNA types } & \multirow{2}{*}{$\begin{array}{c}\text { Total No of } \\
\text { patterns }\end{array}$} \\
\hline & & $\begin{array}{c}A \\
(N 1)\end{array}$ & $\begin{array}{c}B \\
(N 3)\end{array}$ & $\begin{array}{c}C \\
(N 2)\end{array}$ & $D$ & $\begin{array}{c}E \\
(S)\end{array}$ & $F$ & $\begin{array}{c}G \\
(R)\end{array}$ & $H$ & $I$ & $J$ & \\
\hline atp6 & 2 & 2 & 2 & 2 & 2 & 1 & 1 & 2 & 2 & 2 & 2 & 2 \\
\hline $\mathrm{pBv} 4$ & 4 & 2 & 3 & 4 & 5 & 2 & 3 & 1 & 3 & 4 & 3 & 5 \\
\hline Nvulg/N2 & 1 & 1 & 2 & 3 & 1 & 4 & 2 & 5 & 6 & 8 & 3 & 7 \\
\hline
\end{tabular}

The Nvulg type, which is the most frequent type among the maintainers of male sterility used in sugar-beet breeding programmes, is also the most frequent type in 


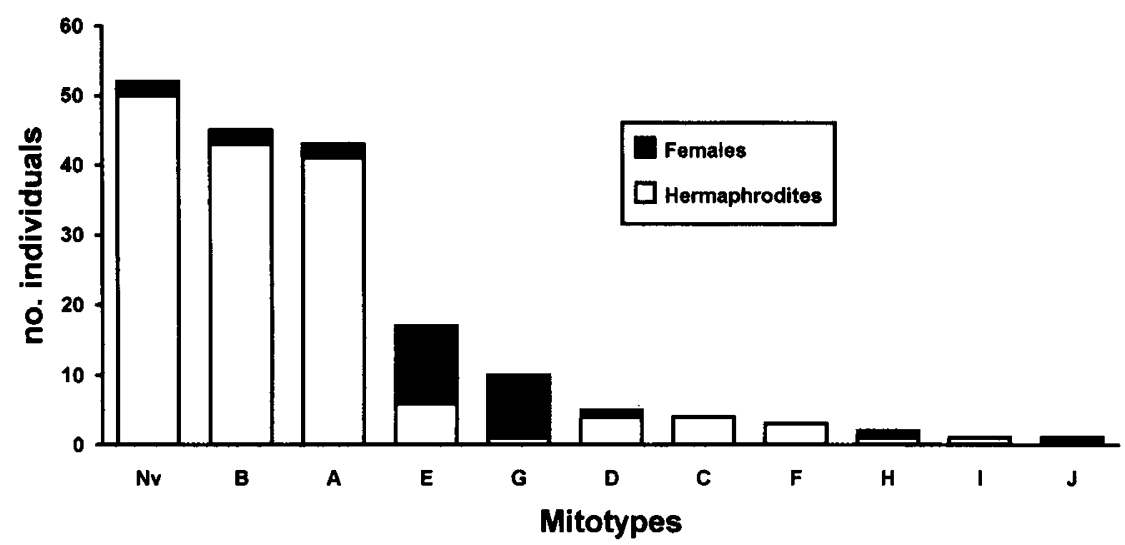

Fig 3. Distribution of female ( $\bullet$ ) and hermaphrodite ( $\square$ ) individuals among the different mitotypes.

natural populations. Conversely, the characteristic pattern of the CMS Owen, the Svulg mitotype, was completely absent from our sample.

There was no clear qualitative difference between the regions; the most frequent types (Nvulg, A, B, E) were found in nearly every region studied (table IV). On the other hand, some rare mitotypes were restricted to only one region, for example, only 5 individuals all from a single population in the Basque region were type D.

Table IV. Regional distribution of the mitochondrial types and association with male sterility. The number of each mtDNA type in each region is indicated together with the female frequency within each mitochondrial type (in italics).

\begin{tabular}{lccccccccccc}
\hline \multirow{2}{*}{ Regions } & \multicolumn{10}{c}{ Mitochondrial DNA types } \\
\cline { 2 - 13 } & Nvulg & $A$ & $B$ & $C$ & $D$ & $E$ & $F$ & $G$ & $H$ & $I$ & $J$ \\
\hline North & 18 & 24 & 5 & 3 & - & 7 & 3 & - & - & - & - \\
& 0.00 & 0.00 & 0.00 & 0.00 & - & 0.57 & 0.00 & - & - & - & - \\
Brittany & 3 & 10 & 21 & 1 & - & 4 & - & 10 & - & - & - \\
& 0.00 & 0.00 & 0.09 & 0.00 & - & 0.75 & - & 0.90 & - & - & - \\
Biscay & 11 & 3 & 19 & - & 5 & 1 & - & - & 1 & 1 & - \\
& 0.00 & 0.00 & 0.00 & - & 0.20 & 1.00 & - & - & 1.00 & 0.00 & - \\
Gers & 16 & - & - & - & - & 3 & - & - & 1 & - & - \\
& 0.00 & - & - & - & - & 0.66 & - & - & 0.00 & - & - \\
Mediterranean & 4 & 6 & - & - & - & 2 & - & - & - & - & 1 \\
Total No & 0.50 & 0.33 & - & - & - & 0.50 & - & - & - & - & 1.00 \\
Mean female & 52 & 43 & 45 & 4 & 5 & 17 & 3 & 10 & 2 & 1 & 1 \\
frequency & 0.04 & 0.05 & 0.04 & 0.00 & 0.20 & 0.65 & 0.00 & 0.90 & 0.50 & 0.00 & 1.00 \\
\hline
\end{tabular}


There was a large variability of mitotypes within the populations; 2.10 different mitotypes on average ( $\mathrm{SE}=0.88$ ) were found among the 5 individuals sampled per population. Nevertheless, there were highly significant overall differences in mitotype frequencies between populations $(F s t=0.466 ; P<0.001)$. The mitotype frequencies varied significantly both between regions $(F s t=0.138 ; P<0.001)$ and between the populations within the regions $(F s t=0.381 ; P<0.001)$.

\section{Male sterility and mitochondrial polymorphism}

Over the whole studied geographical area, there was no strict qualitative association between the sexual phenotype and the mitotype of the plants (fig 3). Female plants did not always have the same mitotype and indeed displayed almost all the different mitotypes. Nevertheless, 2 groups of mitotypes can be clearly distinguished according to the occurrence of male sterility: the mitotypes Nvulg, A and B were rarely associated with the female phenotype, whereas female plants were often found among the plants of mitotypes $\mathrm{E}$ and $\mathrm{G}$. The sample size did not allow analysis of the relationship between the other rare mitotypes and male sterility.

The association between male sterility and mitochondrial polymorphism varied among regions (table IV). In the north region, the female phenotype was closely associated with mitotype E. This mitotype was also found in the other regions where it was also regularly associated with the female phenotype. In Brittany, another highly sterile mitotype, G, was found. Finally, mitotypes Nvulg and A, only rarely associated with the female phenotype in coastal populations from the Basque region to the Netherlands, were closely associated with male sterility in the Mediterranean region.

\section{DISCUSSION}

\section{Gynodioecy in wild beet populations}

This study shows that the occurrence of female plants in natural populations of Beta vulgaris ssp maritima is a common characteristic of its breeding system. Indeed, gynodioecious populations were found in every part of the sampled geographical area.

Female frequency differed widely (from 0 to $76 \%$ ) between populations. This large variation was apparent even on a local scale, between populations less than $1 \mathrm{~km}$ apart, in some of the estuaries of the Channel coast. A comparison of our results with those from the literature shows that wild beet belongs to species with moderate to high levels of male sterility (table V).

Since the inaugural paper of Lewis (1941), many population genetic models have examined the conditions for the maintenance of females at high (and variable) frequencies. Initially dealing with nuclear inheritance of male sterility (Lloyd, 1976; Charlesworth and Charlesworth, 1978), they have gradually taken into account a nucleo-cytoplasmic control of the sexual phenotype variation (Charlesworth, 1981; Delannay et al, 1981; Frank, 1989; Gouyon et al, 1991). In nucleo-cytoplasmic models, male sterility has been seen as a result of an evolutionary conflict between cytoplasmic and nuclear genomes concerning resource allocation to production of 
Table V. Variation of female frequency (as a percentage) in various gynodioecious species.

\begin{tabular}{lccl}
\hline Species & Minimum & Maximum & \multicolumn{1}{c}{ Authors } \\
\hline Plantago lanceolata & 4 & 22 & Van Damme, 1984 \\
Plantago lanceolata & 2 & 31 & Krohne et al, 1980 \\
Plantago coronopus & 5 & 27 & Koelewijn, 1993 \\
Geranium maculatum & 0 & 24 & Ägren and Willson, 1991 \\
Nemophila menziezii & 0 & 26 & Ganders, 1978 \\
Scandia geniculata & 7 & 25 & Webb, 1979 \\
Gingidia spp & 0 & 31 & Webb, 1979 \\
Lignocarpa carnolusa & 0 & 41 & Webb, 1979 \\
Hebe strictissima & 1 & 34 & Delph, 1990 \\
Fuschia excorticata & 4 & 40 & Godley, 1955 \\
Bidens spp & 9 & 44 & Sun and Ganders, 1986 \\
Cortaderia richardii & 0 & 53 & Connor, 1963 \\
Sarcocornia quinqueflora & 0 & 53 & Connor, 1984 \\
Cucurbita foetidissima & 21 & 65 & Kohn, 1989 \\
Thymus vulgaris & 5 & 95 & Dommée al, 1983 \\
Thymus zygis & 17 & 87 & Manicacci, 1993 \\
Thymus mastichina & 41 & 99 & Manicacci, 1993 \\
Beta maritima & 19 & 62 & Boutin et al, 1987 \\
Beta maritima & 0 & 76 & This work \\
\hline
\end{tabular}

male gametes (Cosmides and Tooby, 1981). Selfish, sterilising, cytoplasmic genes tend to spread in populations, and are counteracted by nuclear suppressors of male sterility. The nucleo-cytoplasmic conflict generates varying gene frequencies of both cytoplasmic and nuclear genes, with periods of high female frequencies alternating with periods of low frequencies, or even absence, of females (Frank, 1989; Gouyon et al, 1991).

The framework provided by these theoretical models suggests explanations for the wide spatial variation of the female frequency observed in many gynodicecious species and especially in wild beet. Restricted gene flow leads to population subdivision and consequently to an asynchrony between different populations in the evolutionary dynamics of the nucleo-cytoplasmic, sex-determining system. Thus, spatial variation of female frequencies could be due to geographically variable cytoplasmic and nuclear gene frequencies. The respective contribution of cytoplasmic and nuclear genes to the sex ratio variation between populations has not been established. In particular, 2 important questions remain to be answered: how many cytoplasms determining male sterility are there in populations, and what is the geographical variation of nuclear restorer genes? Indeed, a low frequency of females in a population can be due either to a low frequency of a cytoplasm conferring male sterility or to a high frequency of restorer genes.

All the identified 'cytoplasmic genes' responsible for male sterility have been found within the mitochondrial genome (Newton, 1988; Hanson et al, 1989; Hanson, 1991). The increasing availability of fast and efficient molecular techniques allows specific genetic markers for the mitochondrial genome to be developed. These 
markers can be used to characterise the polymorphism of mitochondrial DNA and to analyse the distribution of the cytoplasms in populations.

\section{Polymorphism of the mitochondrial DNA}

We found 11 different mitochondrial types. Five of them have previously been reported (Saumitou-Laprade et al, 1993), and a sixth, the $\mathrm{H}$ type, identified by Boudry et al (1993). The mitotype Nvulg was the most frequent type found in the natural populations investigated. This type is frequent among the maintainers of male sterility used in the breeding programmes of sugar-beet cultivars. Its wide occurrence in natural populations confirms the close relatedness of cultivated and wild beets.

Conversely, the Svulg mitochondrial type, specific to the CMS Owen cytoplasm used in the breeding programs, was not found during this study. However, its occurrence in wild populations has been reported by several authors. It occurs in wild beet in Turkey (Mikami et al, 1985; Halldén et al, 1988), suggesting that the Owen cytoplasm may have its origin in populations of Beta maritima from this country. Our results suggest that it does not originate from the natural populations in the coastal regions of France. Svulg has been also regularly found in French inland populations of weed beet (Boudry et al, 1993), but in this case, its occurrence is likely to be due to the escape of sugar-beet cultivars, introgressed by early flowering types, present in some seed production areas.

There are few reports in the literature of screening natural populations for mtDNA polymorphism. Our study demonstrates a high level of polymorphism, although it is lower than the remarkably large variation found in Thymus vulgaris (Atlan, 1991). As the rate of evolution of plant mitochondrial genomes and its variation between species is unclear, further studies are needed to assess the variation of mitochondrial polymorphism in natural populations of gynodioecious and non-gynodioecious species.

Although the variability within populations was large (2.1 mtDNA types on average among the 5 individuals sampled), the differences in the mitotype frequencies between populations was highly significant. This demonstrates that wild-beet seed migration is limited and that there is population subdivision for cytoplasmic genes in this species. Thus, it is likely that populations could be at different stages of the dynamic process suggested by theoretical models. Examination of the association between mitotypes and male sterility gives an insight to this issue.

\section{Male sterility and mitochondrial polymorphism}

Female individuals of almost all of the different mitotypes were found. However, high frequencies of male sterility were associated with 2 types: $E$ and G. Type $E$ was found in every region, whereas the $G$ type was only found in populations from Brittany. The relationship between male sterility and mtDNA polymorphism in the populations from the Mediterranean region is unclear and needs further investigation. Thus, our results suggest that only 2 highly sterile cytoplasms are largely responsible for male sterility in the coastal populations of western France. Nevertheless, this has to be confirmed by further genetic analysis using reciprocal 
controlled crosses between plants having different mitotypes or having the same mitotype but originating from different regions: the true number of different male sterile cytoplasms could thereby be determined. Indeed, nothing is known about the molecular basis of male sterility in Beta and the haplotypes defined by combining the different probes have to be considered as genetic markers in linkage disequilibrium with the male sterile cytoplasms.

Our results confirm that the concept of totally fertile cytoplasm used by plant breeders is an oversimplification and that 'normal' cytoplasms are likely to be 'old' sterile types having almost completely fixed their restorer genes. On the other hand, although male sterility may be found with all the mitotypes, we show a preferential association between male sterility and 2 particular mitotypes across a large geographical area. This suggests that in Beta vulgaris ssp maritima, the geographical variation of nuclear restorer gene frequencies is limited.

The comparison of our results with the predictions of theoretical models suggests that the dynamics of male sterility in Beta populations is slow. The widespread distribution of the types, especially those associated with male sterility, raises 2 questions of particular importance for the management of genetic resources:

1) Why do the sterile types never seem to be fully restored, in any location? Further studies should investigate, using a larger sample size, the spatial variation of restorer genes among populations at different levels, from local neighbourhoods to large geographical regions.

2) Why are most mitotypes found in every region? This could result either from distribution of mitotypes to different regions by migration, in which case all copies of the same mitotype would have a single common ancestor and thus be identical by descent, or from independent recurrent mutations. This question arises because of the latent turbulence of the plant mitochondrial genome. The tempo and mode of evolution of mitochondrial genome within species are poorly known, although this gene is thought to evolve rapidly in structure through homologous recombination, but slowly in sequence (Palmer and Herbon, 1988). However, the frequency of rearrangements within species and, in particular, the generating rate of male sterile cytoplasms are still not known and need further investigation.

\section{ACKNOWLEDGMENTS}

We are very grateful to G Béna, P Boudry, P de Laguérie and M Valero for their critical reading of the manuscript. This work was supported by the MRT 'Ressources Génétiques' grant No 90.G.0519 and by the 'Contrat de Plan Etat/Région Nord-Pas-de-Calais 19891993: Maîtrise de la Qualité des Produits Agrolimentaires'. D Forcioli was supported by the MRT allocation No 90680 .

\section{REFERENCES}

Ägren J, Willson MF (1991) Gender variation and sexual differences in reproductive characters and seed production in gynodioecious Geranium maculatum. Am J Bot $78,470-480$

Atlan A (1991) Sexe et hérédité maternelle: évolution de la stérilité mâle chez Thymus vulgaris L. Thèse de doctorat de l'université de Montpellier II 
Baker HG (1966) The evolution, functioning and breakdown of heteromorphic incompatibility sytems. 1. The Plumbaginaceae. Evolution 20, 349-368

Belhassen E, Trabaud L, Couvet D, Gouyon PH (1989) An example of nonequilibrium processes: gynodioecy of Thymus vulgaris L in burned habitats. Evolution 43, 662-667

Belhassen E, Dommée B, Atlan A, Gouyon PH, Pomente D, Assouad MW, Couvet D (1991) Complex determination of male sterility in Thymus vulgaris L: genetic and molecular analysis. Theor Appl Genet 82, 137-143

Boudry P, Mörchen M, Saumitou-Laprade P, Vernet P, Van Dijk H (1993) The origin and evolution of weed beets: consequences for the breeding and release of herbicide resistant transgenic sugar beets. Theor Appl Genet, 87, 471-478

Boutin V, Pannenbecker G, Ecke W et al (1987) Cytoplasmic male sterility and nuclear restorer genes in a natural population of Beta maritima: genetical and molecular aspects. Theor Appl Genet 73, 625-629

Boutin-Stadler V, Saumitou-Laprade P, Valero M, Jean R, Vernet P (1989) Spatiotemporal variation of female frequencies in 2 natural populations of Beta maritima. Heredity 63, 395-400

Charlesworth D (1981) A further study of the problem of the maintenance of females in gynodioecious species. Heredity 46, 27-39

Charlesworth D, Charlesworth B (1978) Population genetics of partial male-sterility and the evolution of monoecy and dioecy. Heredity 41, 137-153

Connor HE (1963) Breeding system in New Zealand grasses. IV. Gynodioecism in Cortaderia. N Z J Bot 1, 258-264

Connor HE (1984) Gynodioecism in Sarcocornia quinqueflora (Salicorniaceae) in New Zealand. $N Z J$ Bot 22, 433-439

Cosmides LM, Tooby J (1981) Cytoplasmic inheritance and intragenomic conflict. $J$ Theor Biol 89, 83-129

Couvet D, Atlan A, Belhassen E, Gliddon CJ, Gouyon PH, Kjellberg F (1990) Coevolution between 2 symbionts: the case of cytoplasmic male sterility in higher plants. Oxford Survey Evol Biol 7, 225-249

Darwin C (1877) The Different Forms of Flowers on Plants of the same Species. Murray, London

Delannay X (1978) La gynodioécie chez les angiospermes. Nat Belges 59, 223-235

Delannay X, Gouyon PH, Valdeyron G (1981) Mathematical study of the evolution of gynodioecy with cytoplasmic inheritance under the effect of a nuclear gene. Genetics 99, 169-181

Delph LF (1990) Sex-ratio variation in the gynodioecious shrub Hebe strictissima (Scrophulariaceae). Evolution 44, 134-142

Dewey RE, Levings CS, Timothy DH (1985) Nucleotide sequence of ATPase subunit 6 of maize mitochondria. Plant Physiol 79, 914-919

Dommée B, Guillerm JL, Valdeyron G (1983) Régime de reproduction et hétérozygotie des populations de Thymus vulgaris L., dans une succession postculturale. CR Acad Sci Paris 296, 111-114

Excoffier L, Smouse PE, Quattro JM (1992) Analysis of molecular variance inferred from metric distances among DNA haplotypes: applications to human mitochondrial DNA restriction data. Genetics 131, 479-491 
Franck SA (1989) The evolutionary dynamics of cytoplasmic male sterility. Am Natur 133, 345-376

Ganders FR (1978) The genetics and evolution of gynodioecy in Nemophila menziesii (Hydrophyllaceae). Can J Bot 56, 1400-1408

Godley EJ (1955) Breeding in New Zealand plants. I. Fuschia. Ann Bot 19, 549-559 Gouyon PH, Vichot F, Van Damme JMM (1991) Nuclear-cytoplasmic male sterility: single point equilibria versus limit cycles. Am Natur 137, 498-514

Halldén C, Bryngelsson I, Bosemark NO (1988) Two new types of cytoplasmic male sterility found in wild Beta beets. Theor Appl Genet 75, 561-568

Halldén C, Lind C, Säll T, Bosemark NO, Bengtsson BO (1990) Cytoplasmic male sterility in Beta is associated with structural rearrangements of the mitochondrial DNA and is not due to interspecific organelle transfer. J Mol Biol 31, 365-372

Hanson MR (1991) Plant mitochondrial mutations and male sterility. Ann Rev Genet 25, 461-486

Hanson MR, Pruitt KD, Nivison HT (1989) Male sterility loci in plant mitochondrial genomes. Oxford Surveys Plant Mol Cell Biol 6, 61-85

Kaul MLH (1988) Male sterility in higher plants. Monographs on Theoretical and Applied Genetics, Springer Verlag, Berlin

Kheyr-Pour A (1980) Nucleo-cytoplasmic polymorphism for male sterility in Origanum vulgare L. J Heredity 71, 253-260

Kheyr-Pour A (1981) Wide nucleo-cytoplasmic polymorphism for male sterility in Origanum vulgare L. J Heredity 72, 45-51

Koelewijn HP (1993) On the genetics and ecology of sexual reproduction in Plantago coronopus. $\mathrm{PhD}$ thesis, State University Utrecht

Kohn JR (1989) Sex ratio, seed production, biomass allocation, and the cost of male function in Cucurbita foetidissima HBK (Cucurbitaceae). Evolution 43, 1424-1434 Krohne DT, Baker I, Baker HG (1980) The maintenance of the gynodioecious breeding system in Plantago lanceolata L. Amer Midl Natur 103, 269-279

Lewis D (1941) Male sterility in natural populations of hermaphrodite plants. New Phytol 40, 56-63

LLoyd DG (1976) The transmission of genes via pollen and ovules in gynodioecious angiosperms. Theor Pop Biol 9, 299-316

Manicacci D (1993) Evolution et maintien de la gynodioecie: allocation sexuelle et structuration spatiale du polymorphisme nucléo-cytoplasmique. Etude théorique et approches expérimentales dans le genre Thymus. Thèse de Doctorat de l'Université de Montpellier II

Mann V, McIntosh L, Theurer C, Hirschberg J (1989) A new cytoplasmic male sterile genotype in the sugar beet Beta vulgaris L: a molecular analysis. Theor Appl Genet 78, 293-297

Mikami T, Kishima Y, Sugiara M, Kinoshita T (1985) Organelle diversity in sugar beet with normal and different sources of male sterile cytoplasms. Theor Appl Genet $71,166-171$

Newton KJ (1988) Plant mitochondrial genomes: organization, expression and variation. Ann Rev Plant Phys Plant Mol Biol 39, 503-532

Owen FV (1945) Cytoplasmically inherited male sterility in sugar beets. J Agric Res $71,423-440$ 
Palmer JD, Herbon LA (1988) Plant mitochondrial DNA evolves rapidly in structure, but slowly in sequence. $J \mathrm{Mol}$ Evol 28, 87-97

Rouwendal GSA, Van Damme JMM, Wessels JGH (1987) Cytoplasmic male sterility in Plantago lanceolata L: differences between male sterile cytoplasms at the DNA and RNA level. Theor Appl Genet 75, 59-65

Saumitou-Laprade P, Rouwendal GJA, Cuguen J, Krens FA, Michaelis G (1993) Different CMS sources found in Beta vulgaris ssp maritima: mitochondrial variability in wild populations revealed by a rapid screening procedure. Theor Appl Genet $85,529-535$

Sun M, Ganders FR (1986) Female frequencies in gynodioecious populations correlated with selfing rates in hermaphrodites. $A m J$ Bot 73, 1645-1648

Van Damme JMM (1983) Gynodioecy in Plantago lanceolata L. II. Inheritance of 3 male-sterile types. Heredity 50, 253-273

Van Damme JMM (1984) Gynodioecy in Plantago lanceolata L. III. Sexual reproduction and the maintenance of male steriles. Heredity 52, 77-93

Vekemans X, Lefebvre C, Belalia L, Meerts P (1990) The evolution and breakdown of the heteromorphic incompatibility system of Armeria maritima revisited. Evol Trends Plants 4, 15-23

Webb CJ (1979) Breeding systems and the evolution of dioecy in New Zealand apioid Umbelliferae. Evolution 33, 662-672 